\title{
Genetic differentiation of deep-sea hydrothermal vent alvinellid populations (Annelida: Polychaeta) along the East Pacific Rise
}

\author{
DIDIER JOLLIVET* ${ }_{\dagger} \neq$, DANIEL DESBRUYĖRES $\ddagger$, FRANÇOIS BONHOMME§ \& DARIO \\ MORAGAT \\ $\dagger$ Plymouth Marine Laboratory, Molecular Biology Department, Citadel Hill, Plymouth PL1 2PB, U.K., $\ddagger$ URM 7 , \\ Laboratoire d'Ecologie Abyssale, DROIEP, IFREMER, Centre de Brest, BP70, 29280, Plouzané, France, §Laboratoire \\ Génome et Populations, URA CNRS 1493, Université de Montpellier II, Place Eugène Bataillon, CC. 63, 34095, \\ Montpellier, France and TURA CNRS D1513, Institut d'Études Marines, Université de Bretagne Occidentale, 6, avenue \\ Le Gorgeu, BP 452, 29275, Brest, France
}

\begin{abstract}
The alvinellid polychaetes, which live in the hottest part of the deep-sea hydrothermal environment, have a nested island-like distribution and locally are subjected to extinctions. They are sedentary and exhibit a peculiar reproductive behaviour and a development which may result in little or no planktonic stage (i.e. larval dispersal). The genetic variation within and among populations of the three main species (Alvinella pompejana, Alvinella caudata and Paralvinella grasslei) inhabiting vents along the East Pacific Rise was examined at a hierarchy of spatial scales using allozyme electrophoresis. The genetic diversity of $P$. grassle $i$ is high $\left(H_{\mathrm{o}}=0.24\right)$, about twice that of both the Alvinella species $\left(H_{\mathrm{o}}=0.10\right)$. The three species show a strong tendency towards a heterozygote deficiency which systematically occurs at the same loci in nearly all the populations. These structures are particularly obvious in the genus Alvinella and might be explained by differential allozyme fitness. Populations display considerable genetic differentiation at the microgeographical scale, which could be explained by repeated founder effects in populations, but it varies from species to species according to their possible ability to be transported by crabs from vent to vent. However, the genetic variation among populations separated by at least $1000 \mathrm{~km}$ is of the same magnitude as that found within the $13^{\circ} \mathrm{N} / \mathrm{EPR}$ segment. These results demonstrate that each species maintains its genetic identity along the oceanic rifts despite the evidence for founder effects. To explain this phenomenon, we hypothesize that in such a harsh environment, genetic drift in alvinellid populations could be balanced by a uniform selective pressure stemming from the vent chemistry.
\end{abstract}

Keywords: allozymes, Alvinellidae, $F_{\mathrm{ST}}$, genetic variation, hydrothermal vents.

\section{Introduction}

Genetic variation in subdivided populations at equilibrium results from a balance between gene flow, natural selection and genetic drift. In sessile marine invertebrates, numerous studies have reported a correspondence between the ability of larvae to disperse and the amount of genetic differentiation between populations. It is generally admitted that a long larval planktonic phase favours extensive gene flow resulting in little differentiation among populations over large geographical distances, whereas a short

${ }^{*}$ Correspondence. dispersal period or direct development are the main grounds for significant differences between marine populations (Avise, 1994). Nevertheless, whatever the dispersal strategy adopted by organisms, local genetic differentiation in populations may also be a result of selection and/or some form of drift derived from bottleneck effects.

Fauna inhabiting deep-sea hydrothermal vents represent ideal biological material with which to study the relative contributions of these influences. These endemic organisms experience natural radioactivity (Cherry et al., 1992), hypoxia and high concentrations of sulphide, ammonia and heavy metals (Edmond et al., 1982) which greatly exceed any recorded for either 
marine or terrestrial environments. They exhibit a marked linear hierarchy in the spatial arrangement of their populations. Vents are clustered to form hydrothermal fields of a few hundred metres in length, fields are linearly clustered for tens of kilometres within active spreading segments, and ridge segments are separated by transform faults and by distances which can be hundreds of kilometres. At the highest scale, the separate ridges are spaced thousands of kilometres apart (Tunnicliffe, 1991). As a consequence, this island-like arrangement of vents along the ridge axes results in a peculiar, nested distribution of many ventendemic species. As the geographical distance separating vents increases, the number of shared species seems to decrease (Tunnicliffe, 1988; Hessler \& Lonsdale, 1991). At the population level, gene flow estimates should also decrease with geographical distance as predicted by the one-dimensional stepping stone model of Kimura \& Weiss (1964). In addition, the environment is characterized by great spatial and temporal instability as a result of tectonic and magmatic events or the dynamic properties of the hydrothermal convection through the basaltic crust of the oceanic rifts (Hessler et al, 1988; Watremez \& Kervevan, 1990; Jollivet, 1993; Haymon et al., 1993). The hydrothermal activity shifts along the spreading axes and generates numerous short-lived vents (1-100 years: Lalou, 1991), thus causing catastrophic and chaotic extinctions in populations and inducing the need of a continual colonization of the new active vents (Hessler et al., 1988; Jollivet, 1993). Such an ecological situation may alter the expectations of the one-dimensional stepping stone model which assumes that local populations must be sufficiently stable over time to reach an equilibrium between drift and gene flow.

Several population genetic studies have been conducted on deep-sea hydrothermal vent molluscs (Grassle, 1985; Denis et al., 1993; Vrijenhoek et al., 1993), vestimentiferan tube-worms (Bucklin, 1988; Black, 1991) and amphipods (France et al., 1992). Surprisingly, the results sometimes show a significant variation, and sometimes a lack of variation between well-separated populations which is not clearly related to their dispersal ability but could be explained by selection and genetic drift.

The alvinellid polychaetes are restricted to deep-sea hydrothermal vents. Most of them, especially species belonging to the genus Alvinella, live on the hydrothermal chimneys where in situ ambient temperatures can occasionally reach up to $105^{\circ} \mathrm{C}$ (Chevaldonné et al. 1992). Previous studies on their reproduction and larval development (Desbruyères \& Laubier, 1986; McHugh, 1989) show that these species have lecithotrophic erpochaete larvae which could reduce their ability to disperse. More recently, a study has shown that these organisms use internal fertilization to reproduce (Zal et al., 1994) and exhibit an unusual mating behaviour (Chevaldonné \& Jollivet, 1993) which could be interpreted as a mechanism to protect offspring against unstable and extreme environmental conditions. Such reproductive behaviour is known to limit dispersal. Both a restricted dispersion and a high rate of extinction in populations raises the question of how alvinellids colonize their environment and maintain the cohesion of the species' gene pool.

The aim of this study was to examine the genetic variability within and among populations of the three main alvinellid species found along the East Pacific Rise and to test the hypothesis that gene flow decreases as a function of the geographical distance under the neutral assumptions of the stepping stone model.

\section{Materials and methods}

\section{Samples}

Samples of Alvinella pompejana, Alvinella caudata and Paralvinella grasslei were collected at hydrothermal vents along the East Pacific Rise and on the Galapagos Rift (Table 1) using the deep-sea manned submersibles Nautile and Alvin. Collections were made during several cruises supported by the University of Rutgers, New Jersey, the University of California, Santa Barbara and the IFREMER and Woods Hole Institutes. Most of the samples were collected on the walls of active hydrothermal chimneys where temperatures experienced by the organisms varied from $5^{\circ} \mathrm{C}$ (PARIGO site, 1987) to $45^{\circ} \mathrm{C}$ (GENESIS and TOTEM sites, 1990). However, the occurrence of $P$. grasslei on chimneys depended mainly on the environmental conditions and no individuals were found above a temperature of $35^{\circ} \mathrm{C}$. P. grasslei was also sampled living on the vestimentiferan Riftia pachyptila in diffuse venting areas at the GENESIS site in 1987 and the ROSE GARDEN site of the Galapagos Spreading Centre in 1988.

\section{Electrophoretic techniques}

The gills and the anterior part of the body were homogenized in an equal volume of a special extraction buffer described by Denis et al. (1993). This allowed us to avoid inclusion of both the epibiotic bacteria found in the dorsal part of the Alvinella spp. (Desbruyères \& Laubier, 1980) and the chelated heavy metals found in the tissues of these polychaetes (Gaill et al., 1984). Tissue homogenates were centrifuged at $25000 \mathrm{~g}$ for $30 \mathrm{~min}$ at $4^{\circ} \mathrm{C}$ and electrophoresis was conducted for $4-6 \mathrm{~h}$ at $80 \mathrm{~mA}$ using 11 per cent starch gel. The stain- 
Table 1 Location of the different alvinellid polychaete populations sampled along the East Pacific Rise (EPR) using the deepsea manned submersibles Alvin and Nautile since 1984

\begin{tabular}{|c|c|c|c|c|c|c|c|}
\hline Species & Field & Site & Year & Code & $N$ & Location & Depth \\
\hline \multirow[t]{7}{*}{ A. pompejana } & \multirow[t]{6}{*}{$13^{\circ} \mathrm{N}(\mathrm{EPR})$} & POGONORD & 1987 & PO87 & 20 & $12^{\circ} 4861^{\prime} \mathrm{N}-103^{\circ} 5662^{\prime} \mathrm{W}$ & $2635 \mathrm{~m}$ \\
\hline & & PARIGO & 1987 & PA87 & 60 & $12^{\circ} 4852^{\prime} \mathrm{N}-103^{\circ} 5648^{\prime} \mathrm{W}$ & $2630 \mathrm{~m}$ \\
\hline & & ELSA & 1987 & EL87 & 7 & $12^{\circ} 4808^{\prime} \mathrm{N}-103^{\circ} 5634^{\prime} \mathrm{W}$ & $2635 \mathrm{~m}$ \\
\hline & & TOTEM & 1987 & TO87 & 27 & $12^{\circ} 4872^{\prime} \mathrm{N}-103^{\circ} 5653^{\prime} \mathrm{W}$ & $2630 \mathrm{~m}$ \\
\hline & & TOTEM & 1990 & TO90 & 18 & $12^{\circ} 4872^{\prime} \mathrm{N}-103^{\circ} 5653^{\prime} \mathrm{W}$ & $2630 \mathrm{~m}$ \\
\hline & & GENESIS & 1990 & GE90 & 32 & $12^{\circ} 4858^{\prime} \mathrm{N}-103^{\circ} 5647^{\prime} \mathrm{W}$ & $2635 \mathrm{~m}$ \\
\hline & $21^{\circ} \mathrm{N}(\mathrm{EPR})$ & HANGING GARDEN & 1990 & HG90 & 21 & $20^{\circ} 5030^{\prime} \mathrm{N}-109^{\circ} 0640^{\prime} \mathrm{W}$ & $2595 \mathrm{~m}$ \\
\hline \multirow{6}{*}{ A. caudata } & \multirow{5}{*}{$13^{\circ} \mathrm{N}(\mathrm{EPR})$} & POGONORD & 1987 & PO87 & 19 & $12^{\circ} 4861^{\prime} \mathrm{N}-103^{\circ} 5662^{\prime} \mathrm{W}$ & $2635 \mathrm{~m}$ \\
\hline & & PARIGO & 1987 & PA87 & 32 & $12^{\circ} 4852^{\prime} \mathrm{N}-103^{\circ} 5648^{\prime} \mathrm{W}$ & $2630 \mathrm{~m}$ \\
\hline & & TOTEM & 1987 & TO87 & 50 & $12^{\circ} 4872^{\prime} \mathrm{N}-103^{\circ} 5653^{\prime} \mathrm{W}$ & $2630 \mathrm{~m}$ \\
\hline & & TOTEM & 1990 & TO90 & 23 & $12^{\circ} 4872^{\prime} \mathrm{N}-103^{\circ} 5653^{\prime} \mathrm{W}$ & $2630 \mathrm{~m}$ \\
\hline & & GENESIS & 1990 & GE90 & 19 & $12^{\circ} 4858^{\prime} \mathrm{N}-103^{\circ} 5647^{\prime} \mathrm{W}$ & $2635 \mathrm{~m}$ \\
\hline & $21^{\circ} \mathrm{N}(\mathrm{EPR})$ & HANGING GARDEN & 1990 & HG90 & 33 & $20^{\circ} 5030^{\prime} \mathrm{N}-109^{\circ} 0640^{\prime} \mathrm{W}$ & $2595 \mathrm{~m}$ \\
\hline \multirow[t]{7}{*}{ P. grasslei } & \multirow[t]{3}{*}{$13^{\circ} \mathrm{N}(\mathrm{EPR})$} & PARIGO & 1987 & PA87 & 22 & $12^{\circ} 4852^{\prime} \mathrm{N}-103^{\circ} 5648^{\prime} \mathrm{W}$ & $2630 \mathrm{~m}$ \\
\hline & & GENESIS & 1987 & GE87 & 32 & $12^{\circ} 4858^{\prime} \mathrm{N}-103^{\circ} 5647^{\prime} \mathrm{W}$ & $2635 \mathrm{~m}$ \\
\hline & & GENESIS & 1990 & GE90 & 34 & $12^{\circ} 4858^{\prime} \mathrm{N}-103^{\circ} 5647^{\prime} \mathrm{W}$ & $2635 \mathrm{~m}$ \\
\hline & $21^{\circ} \mathrm{N}(\mathrm{EPR})$ & HANGING GARDEN & 1990 & HG90 & 33 & $20^{\circ} 5030^{\prime} \mathrm{N}-109^{\circ} 0640^{\prime} \mathrm{W}$ & $2595 \mathrm{~m}$ \\
\hline & $11^{\circ} \mathrm{N}(\mathrm{EPR})$ & UNNAMED VENT & 1990 & VE90 & 40 & $11^{\circ} 2630^{\prime} \mathrm{N}-103^{\circ} 4730^{\prime} \mathrm{W}$ & $2600 \mathrm{~m}$ \\
\hline & Galapagos & ROSE GARDEN & 1988 & RG88 & 9 & $00^{\circ} 4825^{\prime} \mathrm{N}-86^{\circ} 1348^{\prime} \mathrm{W}$ & $2450 \mathrm{~m}$ \\
\hline & Guaymas & UNNAMED VENT & 1985 & GU85 & 12 & $27^{\circ} 0035^{\prime} \mathrm{N}-111^{\circ} 2458^{\prime} \mathrm{W}$ & $2010 \mathrm{~m}$ \\
\hline
\end{tabular}

$N$ : sample size.

ing recipes were those provided in Harris \& Hopkinson (1976) and Pasteur et al. (1987). The assayed enzymes and the buffer media are listed in Table 2 . The $A$. pompejana specimens collected at the site POGONORD in 1987 were arbitrarily chosen as our reference population for numbering alleles according to their relative mobility.

\section{Analysis}

For each alvinellid colony, the BIosys-1 program (version 1.6) of Swofford \& Selander (1989) was used to compute the allele frequencies at a given locus, to test for deviations from Hardy-Weinberg equilibrium and to estimate the levels of polymorphism and heterozygosities. Expected genotype frequencies were estimated using Levene's formula (1949) and tested by employing either $\chi^{2}$, Yates's $\chi^{2}$ and $G$-tests or the exact significance probabilities (Vithayasai, 1973).

We analysed heterozygote deficiencies of each population using the $F$-statistic $F_{\text {IS }}$ (Wright, 1965) estimated according to Nei (1977). This statistic measures the deviation of genotype frequencies from the Hardy-Weinberg model within a subpopulation and takes a positive value when a heterozygote deficiency occurs.
To analyse the differentiation across alvinellid populations, we performed both a pairwise analysis using three estimators of gene flow and a spatial hierarchical analysis using $F$-statistics.

To estimate gene flow, we calculate $\mathrm{Nm}$ (the effective number of migrants exchanged per generation across two populations) from pairwise combinations of samples within each species. Assuming that the estimator $G_{\text {ST }}$ (Nei, 1977) and Weir \& Cockerham's (1984) coancestry $\theta$ provide reliable estimates of $F_{\mathrm{ST}}$ (Slatkin and Barton, 1989), we calculated $N m$ using Wright's (1965) infinite island model formula: $\left.N m=\left(1 / F_{\mathrm{ST}}-1\right)\right\rangle$ 4 , which relies on the assumptions that alleles are neutral and that mutation and migration are in equilibrium. First, we used genotype frequency data to calculate $G_{\mathrm{ST}}$ employing the computer program BIOSYS-1 (Swofford \& Selander, 1989). Secondly, we calculated $\theta$ from the same set of data employing the program DIPLOID.FOR (Weir, 1990). The third approach to estimate $N m$ was Slatkin's (1985) 'private allele' method because rare alleles appear to be strongly involved in the genetic variation of alvinellid populations. Following Slatkin's simulation models, $\mathrm{Nm}$ is given by the formula: $\ln [p(1)]=a \cdot \ln (N m)+b$ where $a=-0.505$, $b=-2.440$ and $[p(1)]$ corresponds to the mean frequency of private alleles. 
Table 2 Enzymes assayed for the alvinellid species and buffer conditions used for the electrophoretic separations

\begin{tabular}{|c|c|c|c|}
\hline Enzyme & E.C. No. & Locus & Buffer \\
\hline Aspartate aminotransferase & 2.6.1.1 & Aat-1 & TC 8.0 \\
\hline Aconitase & 4.2.1.3 & $\begin{array}{l}\text { Acoh-1 } \\
\text { Acoh-2 }\end{array}$ & TC 6.7 \\
\hline Acid phosphatase & 3.1 .3 .2 & Acp & $\begin{array}{l}\text { TC } 6.7 \\
\mathrm{LiOH} 7.0\end{array}$ \\
\hline Adenylate kinase & 2.7.4.3 & $A k$ & $\mathrm{THCl} 8.5$ \\
\hline Diaphorase & 1.8.1.4 & $\begin{array}{l}\text { Dia-1 } \\
\text { Dia-2* } \\
\text { Dia-3** }\end{array}$ & $\begin{array}{l}\text { TBE } 8.6 \\
\text { TC } 8.0\end{array}$ \\
\hline $\begin{array}{l}\text { Fumarase } \\
\alpha \text {-Glycerophosphate }\end{array}$ & 4.2 .1 .2 & Fumh* & TC $8.0^{\mathrm{a}}$ \\
\hline $\begin{array}{l}\alpha \text {-Glycerophosphate } \\
\text { dehydrogenase }\end{array}$ & 1.1.1.8 & $\alpha G p d h^{*}$ & $\begin{array}{l}\text { TC } 8.0^{\mathrm{a}} \\
\text { THCl } 8.5\end{array}$ \\
\hline Glucosephosphateisomerase & 5.3 .1 .9 & Gpi & $\begin{array}{l}\text { TC } 8.0 \\
\text { TCB } 8.7\end{array}$ \\
\hline Hexokinase & 2.7.1.1 & $H k-1^{* *}$ & THCl 8.5 \\
\hline Isocitrate dehydrogenase & 1.1.1.42 & $I d h-1$ & TC $8.0^{\mathrm{b}}$ \\
\hline Leucine aminopeptidase (Cytosol) & 3.4.11.1 & $\begin{array}{l}\text { Cap-1 } \\
\text { Cap-2 }\end{array}$ & $\begin{array}{l}\text { TCB } 8.7 \\
\text { TC } 6.7\end{array}$ \\
\hline Malate dehydrogenase & 1.1.1.37 & $\begin{array}{l}M d h-1 \\
M d h-2\end{array}$ & $\begin{array}{l}\text { TC } 6.7^{\mathrm{a}} \\
\text { TC } 8.0^{\mathrm{a}}\end{array}$ \\
\hline Mannosephosphateisomerase & 5.3 .1 .8 & $M p i$ & TC $8.0^{\mathrm{a}}$ \\
\hline Phosphoglucomutase & 5.4 .2 .2 & Pgm & TC 8.0 \\
\hline
\end{tabular}

The buffer abbreviations correspond to those described by Pasteur et al.(1987).

a $25 \mathrm{mg}$ of NAD added to the gel and the cathodal reservoir.

b $25 \mathrm{mg}$ of NADP added to the gel and the cathodal reservoir.

*Allozyme pattern only resolved for the genus Alvinella.

**Allozyme pattern only resolved for Paralvinella grasslei.

The genetic structure of the alvinellid polychaetes was assessed on a hierarchy of spatial scales. The statistics $G_{\mathrm{DS}}$ and $\theta_{\mathrm{DS}}$ (D: deme, S: spreading segment) were obtained from the genotype frequencies of demes within a $2 \mathrm{~km}$ portion of the $13^{\circ} \mathrm{N} / \mathrm{EPR}$ hydrothermal segment, the statistics $G_{\mathrm{DR}}$ and $\theta_{\mathrm{DR}}$ (D: deme, R: oceanic ridge) from the genotype frequencies of populations separated by at least a few hundred kilometres along the East Pacific Rise, and, finally, the single statistics $G_{\mathrm{DT}}$ and $\theta_{\mathrm{DT}}$ (D: deme, T: total) were obtained only for $P$. grasslei from the overall genotypic frequencies. These frequencies include the samples collected on the Galapagos Rift and the Guaymas Basin, which are isolated from the East Pacific Rise by both edaphic and bathymetric characteristics (Guaymas Basin) and the Hess Deep depression (Galapagos Rift) at distances which were commonly greater than $1000 \mathrm{~km}$ (Fig. 1)

We tested the significance of the $F_{\mathrm{IS}}$ and $F_{\mathrm{ST}}$ derived from $G_{\mathrm{ST}}$ at each locus according to Brown (1970) and
Workman and Niswander (1970), respectively. A jackknife procedure was used to combine the information across loci within a population or across populations within a locus, which generated a mean and a standard deviation from the single $F$-statistic estimates. The averages of the $F$-statistics were then compared to zero using a $t$-test (Sokal \& Rohlf, 1981). In addition, Dixon's test for detecting outliers in a normal distribution (Sokal \& Rohlf, 1981) was used on the set of single-locus $G_{\mathrm{ST}}$ and $\theta$ estimates. Indeed, the occurrence of a locus displaying large differences between populations among loci presenting low variation within populations could suggest that one or several alleles at this locus were under natural selection. The correlation of gene flow estimates obtained from $\theta$ with the geographical distance was tested using Mantel's test of the association of two parameters in data matrices with internal correlation (Manly, 1985). This test was performed using one of the procedures of the GENETIX 0.0 package (Bonhomme et al., 1993). 


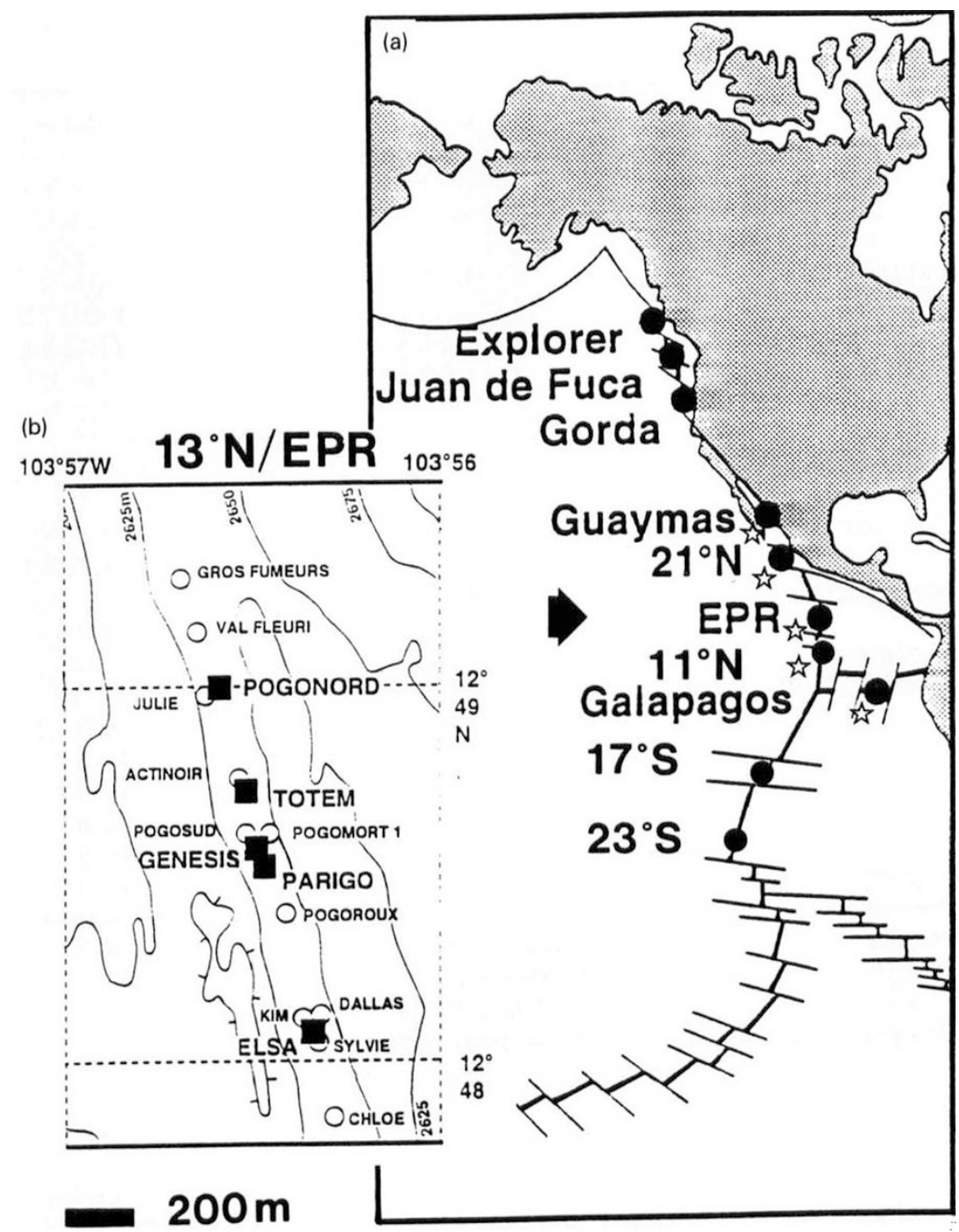

Fig. 1 Location map showing the occurrence of alvinellid species in the Eastern Pacific at two spatial scales: (a) along the East Pacific Rise (EPR) and the Northern Pacific ridges where fields are separated by a few hundred kilometres to a few thousand kilometres (empty stars correspond to the vent collecting sites), (b) within the $13^{\circ} \mathrm{N} / \mathrm{EPR}$ active spreading segment where sites are separated by a few metres to a few tens of metres (black squares correspond to the vent collecting sites).

\section{Results}

\section{Genetic diversity of alvinellids}

The genetic variability of the three alvinellid species is based on 18 putative enzyme loci including eight, nine and four loci monomorphic in all populations of $A$. pompejana, A. caudata and $P$. grasslei, respectively. Most loci of the three species are polymorphic using the 0.99 criterion but the number of observed alleles is much greater for $P$. grasslei than for the Alvinella species (see Appendix). The percentage of polymorphic loci, the observed (direct count) and unbiased expected heterozygosities, and the observed number of alleles for the three species are shown in Table 3. This shows evidence for the occurrence of a high genetic variability in $P$. grasslei $\left(P_{95 \%}=63.5\right.$ and $\left.H_{0}=0.237\right)$ which is about twice that of both the Alvinella species. This difference is emphasized by the fact that for each species, populations display the same level of genetic variability (low standard errors).

\section{Population structure}

For most of the loci, one allele often predominates in nearly all populations whereas the alternative alleles have frequencies which vary greatly at both the segment and ridge spatial scales (see Appendix). The percentage of alleles whose frequency did not exceed 0.1 ranged from 28 per cent $(P$. grasslei) to 42 per cent (A. pompejana). A few loci such as Aat-1 for P. grasslei, $M p i$ for $A$. caudata and $P g m$ for $A$. pompejana, exhibited at least two alleles whose frequencies varied slightly 
Table 3 Genetic variability of the three alvinellid species observed along the East Pacific Rise

\begin{tabular}{lccccc}
\hline Species & $N$ & $P_{95 \%}$ & $H_{\mathrm{o}}$ & $H_{\mathrm{e}}$ & $N_{\mathrm{o}}$ \\
\hline Alvinella pompejana & & & & & \\
Mean & 25.0 & 36.4 & 0.094 & 0.107 & 1.7 \\
SE & $( \pm 5.1)$ & $( \pm 4.3)$ & $( \pm 0.032)$ & $( \pm 0.034)$ & $( \pm 0.2)$ \\
Alvinella caudata & & & & & \\
Mean & 27.6 & 31.7 & 0.110 & 0.118 & 1.8 \\
SE & $( \pm 3.9)$ & $( \pm 3.6)$ & $( \pm 0.038)$ & $( \pm 0.040)$ & $( \pm 0.2)$ \\
Paralvinella grasslei & & & & & \\
Mean & 23.9 & 63.5 & 0.237 & 0.253 & 2.5 \\
SE & $( \pm 4.0)$ & $( \pm 1.6)$ & $( \pm 0.047)$ & $( \pm 0.052)$ & $( \pm 0.3)$ \\
\hline
\end{tabular}

$N$, average number of individuals collected per population.

$P_{95 \%}$, average percentage of polymorphic loci obtained at the $5 \%$ criterion per population.

$H_{\mathrm{o}}$, average observed heterozygosity per population (direct count).

$H_{\mathrm{e}}$, average expected heterozygosity per population (unbiased estimate).

$N_{\mathrm{o}}$, average observed number of alleles per locus in each population. (Values in brackets correspond to the standard error of the mean: $\mathrm{SE}$.)

in samples whereas the occurrence of the other alleles mainly depended on the location of the population (see Appendix).

The Acoh-1, Acoh-2 and Acp loci displayed significant departures from the Hardy-Weinberg equilibrium using an exact probability test (see Appendix) for $A$. pompejana and $P$. grasslei at the 5 per cent level of significance. However, except for one (Acoh-1, TO87), this result was not supported by the Bonferroni procedure (Hochberg, 1988). Assuming that $F_{\text {IS }} \sqrt{ } N$ has a normal distribution under the null hypothesis of the Hardy-Weinberg equilibrium (Brown, 1970), this departure corresponds to a significant heterozygote deficiency. Most of the highest single-locus $F_{\text {IS }}$ estimates were positive and systematically found at the same loci throughout the demes for all these species (Fig. 2). As a consequence, most of the average multilocus $F_{\text {Is }}$ estimates per population were positive for the three species (Table 4), all the positive values being significant (Student's $t$-test; d.f. $=12 ; P<0.05$ ) for $A$. pompejana as well as half of those found for $A$. caudata and $P$. grasslei.

\section{Genetic differentiation between populations}

Pairwise analysis The genetic differentiation between populations is mostly due to the presence/absence of numerous alleles (see Appendix). However, caution must be exercised when pairwise comparisons are made with EL87 ( $A$. pompejana), RG88 and GU85 ( $P$. grasslei) as the presence or absence of rare alleles depends critically on the sample size. Results are presented for each species as a log-scale diagram showing the $\mathrm{Nm}$ variation against the geographical distance (Fig. 3). The three methods provide roughly the same distribution of the $\mathrm{Nm}$ values. However, the values obtained using the 'private allele' method are lower than those calculated from $\theta$ and $G_{\mathrm{ST}}$. When EL87 is removed (small sample size), the $\mathrm{Nm}$ values obtained for $A$. pompejana within the $13^{\circ} \mathrm{N} / \mathrm{EPR}$ segment are low if we consider the average distance between two vents but do not fall below the critical value of 1 , beneath which genetic differentiation of conspecific populations may occur only by random processes (genetic drift). This is not the case for $A$. caudata and $P$. grasslei for which $\mathrm{Nm}$ values appear to be higher. Assuming that alvinellid polychaetes have a low capacity to disperse, these findings do fit the expected theoretical one-dimensional stepping stone model of Kimura and Weiss (1964) at both segment and ridge scales. The curves exhibit patterns which are different according to the species. For $A$. pompejana, $N m$ values are negatively correlated with geographical distance within the segment $13^{\circ} \mathrm{N} / \mathrm{EPR}$ (Fig. 3a) but no clear relationship is shown at the ridge scale (i.e. when the HG90 sample is added; Mantel's test; $g=0.063$; $P=0.438$ ). Conversely, $N m$ values obtained for $A$. caudata do not seem to decrease with increasing distances within the segment $13^{\circ} \mathrm{N} / \mathrm{EPR}$ (Fig. $3 \mathrm{~b}$ ) but a positive relationship emerges at the ridge scale (i.e. when the HG90 sample is added; Mantel's test; $g=0.781 ; P=0.001)$. For $P$. grasslei, $N m$ values show a slight decrease with the geographical distance (Fig. 3c) 


\section{Alvinella pompejana}
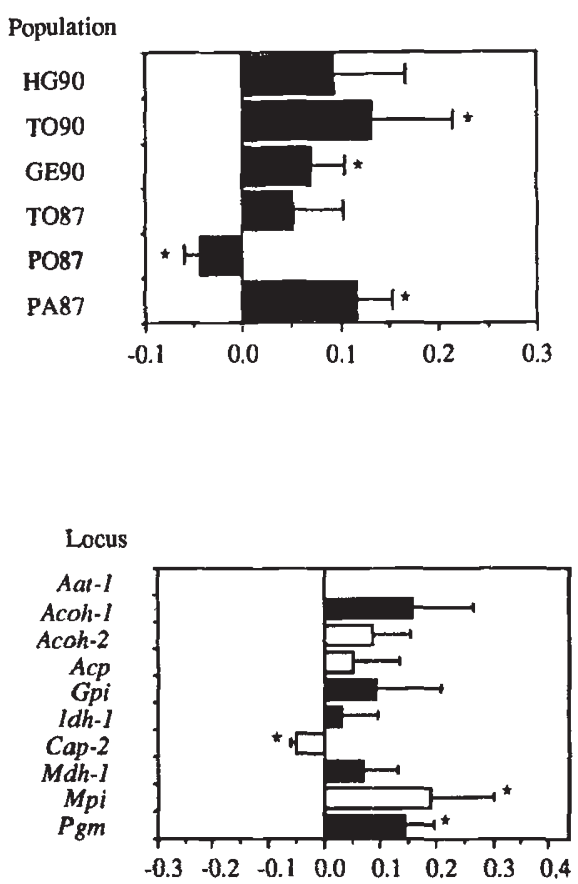

Alvinella caudata

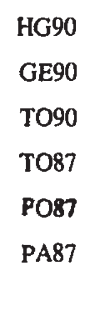

T087

PO87

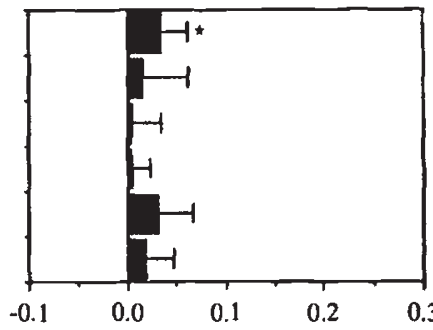

Mean $F_{\text {IS }}$ per population

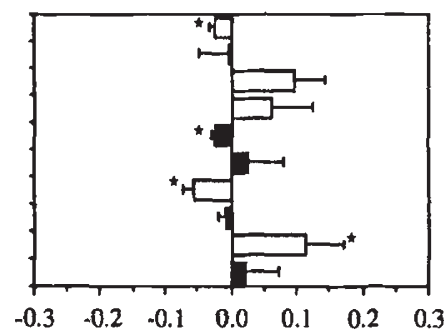

Mean $F_{\text {IS }}$ per locus
Paralvinella grasslei
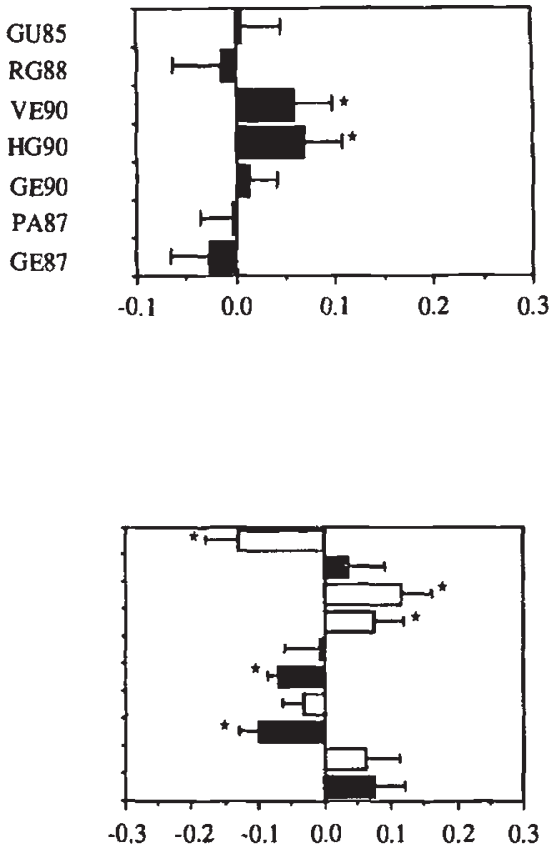

Fig. 2 Histograms showing the genetic structure of the three alvinellid species using Wright's fixation index $\left(F_{\text {IS }}\right)$. White bars correspond to a heterozygote deviation which systematically occurs at a locus in the same direction within and between species. Sample EL87 was excluded because of its small size. ${ }^{*}$ Corresponds to a significant value of the mean fixation index at the 1 per cent level $(t$-test $)$.

Table 4 Wright's fixation index $\left(F_{\text {IS }}\right)$ averaged across loci for each population (within populations) and across populations of each species (across populations) with its jackknife estimate of the standard error

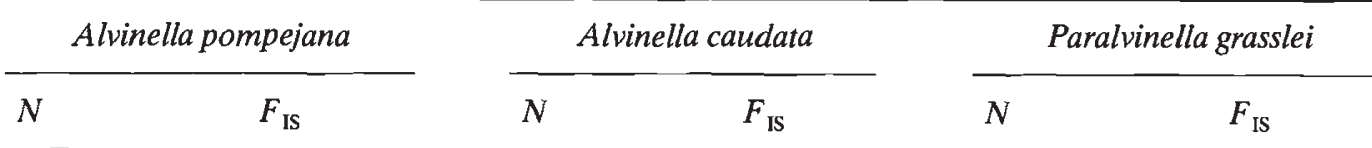

Within populations

$\begin{array}{rcrlrr}50 & 0.116 \pm 0.037^{* * *} & 30 & 0.018 \pm 0.029 & 29 & -0.027 \pm 0.039 \\ 20 & -0.044 \pm 0.017^{* * *} & 19 & 0.031 \pm 0.037^{*} & 20 & -0.004 \pm 0.033 \\ 27 & 0.052 \pm 0.050^{*} & 43 & 0.004 \pm 0.020 & 30 & 0.013 \pm 0.028 \\ 32 & 0.069 \pm 0.035^{* * *} & 22 & 0.003 \pm 0.031 & 32 & 0.070 \pm 0.038^{* * *} \\ 18 & 0.132 \pm 0.081^{* * *} & 19 & 0.015 \pm 0.048 & 39 & 0.058 \pm 0.038^{* * *} \\ 21 & 0.093 \pm 0.074^{*} & 33 & 0.035 \pm 0.028^{* *} & 9 & -0.015 \pm 0.049 \\ 7 & -0.014 \pm 0.032 & & & 12 & 0.006 \pm 0.040\end{array}$

Across populations

$$
0.069 \pm 0.022^{* * *} \quad 0.015 \pm 0.014^{*}
$$

$0.011 \pm 0.023$

All the means are based on 13 or 12 putative enzyme loci and compared to zero using a $t$-test $\left({ }^{*} P \leqslant 0.05,{ }^{* *} P \leqslant 0.01\right.$, $* * * P \leqslant 0.001$ ).

$N$ corresponds to the number of individuals scored to perform analyses. 


\section{Alvinella pompejana}

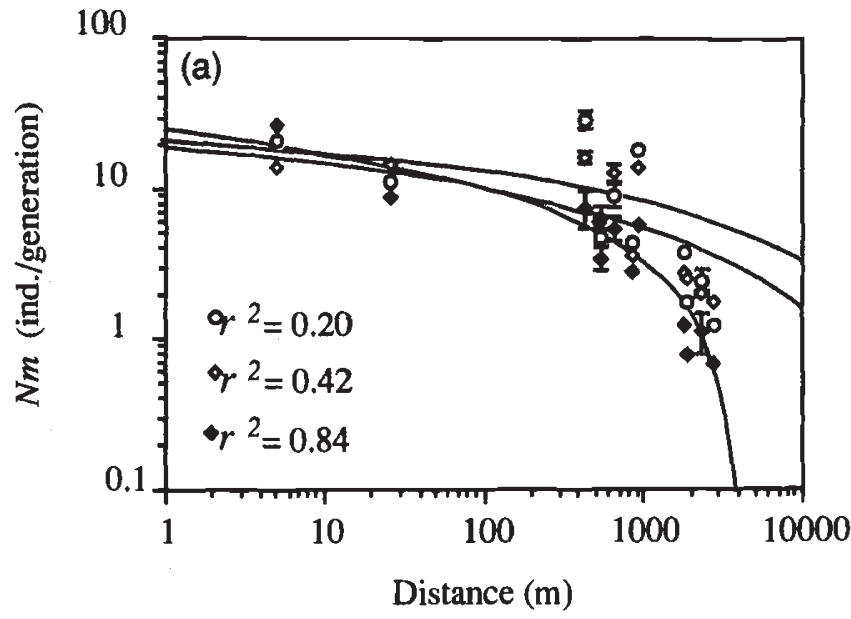

Alvinella caudata

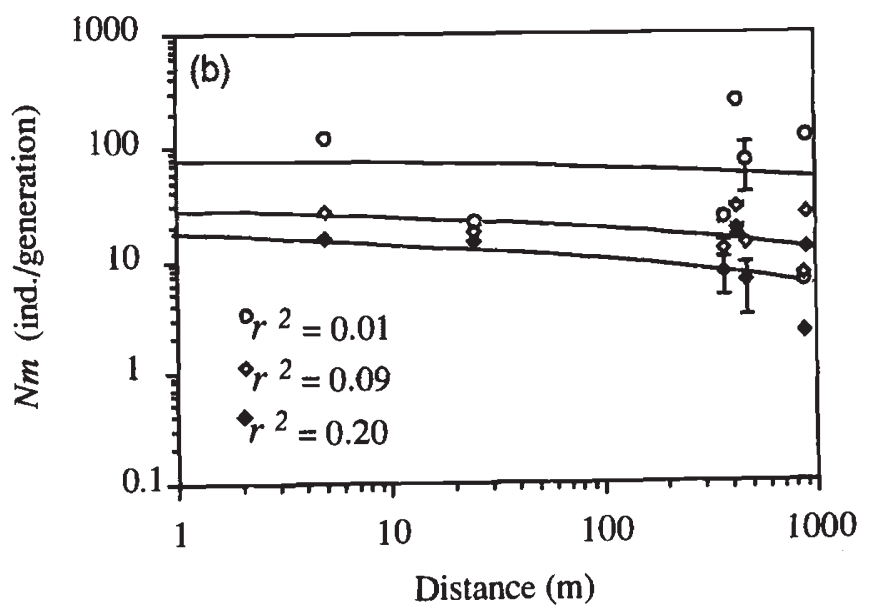

Paralvinella grasslei

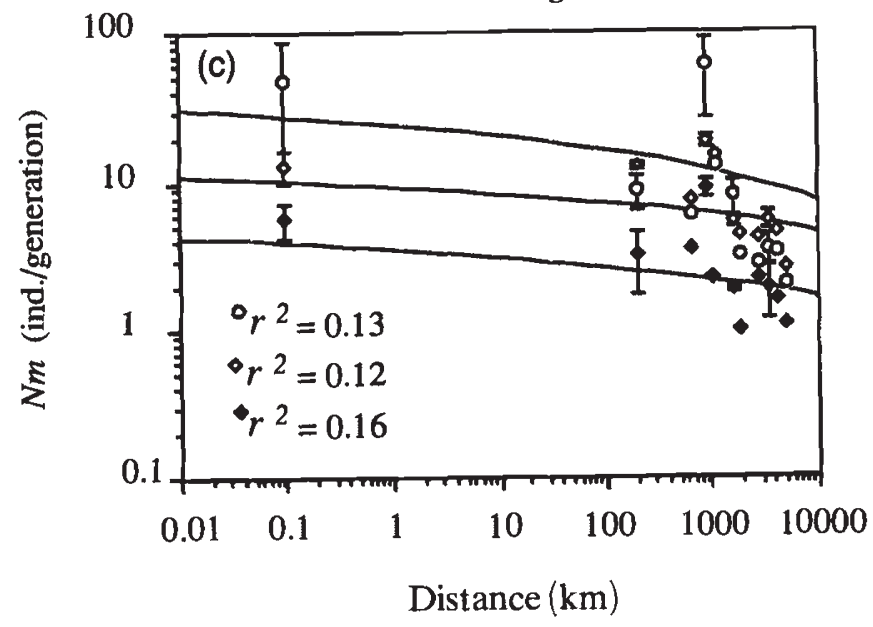

(Mantel's test; $\quad g=2.138 ; \quad P=0.015$ ). These relationships do not support the hypothesis of genetic isolation with geographical distance.

Hierarchical analysis The $F$-statistics obtained from distinct spatial scales are given in Tables 5, 6 and 7 . The $G_{\mathrm{ST}}$ and $\theta$ values give the same trend indicating that genetic differentiation across the alvinellid populations is heterogeneous among loci. Indeed, the values obtained at the segment scale $\left(G_{\mathrm{DS}}\right.$ and $\left.\theta_{\mathrm{DS}}\right)$ at the locus Acoh-2 were four times greater than any other estimates for both A. pompejana and P. grasslei and depart significantly from the distribution of the other single-locus estimates (Dixon's test: $P<0.05$ ). Two jackknife procedures were performed with and without these outliers. In both cases, the average multi-locus $F$ statistics obtained for all the spatial scales (segment: DS, ridge: DR and total: DT) are clearly significantly different from zero (Tables 5, 6 and 7) indicating that populations are sufficiently differentiated to support the hypothesis that these organisms have a low dispersal ability. However, pairwise comparisons between the overall multilocus $G_{\mathrm{DS}}$ or $\theta_{\mathrm{DS}}$ and $G_{\mathrm{DR}}$ or $\theta_{\mathrm{DR}}$ do not show this differentiation to increase with geographical distance along the $1000 \mathrm{~km}$ of the East Pacific Rise for either A. pompejana or $P$. grasslei (Student's $t$-test: $t_{\max }=2.1$, d.f. $=11, P>0.05$ ) in contrast to the situation in $A$. caudata (Student's $t$-test: $t_{\min }=4.4$, d.f. $=11$, $P<0.01$ ). Nevertheless, the level of differentiation among populations of $P$. grasslei significantly increases when comparisons are made between the overall multilocus $G_{\mathrm{DS}}$ or $\theta_{\mathrm{DS}}$ and $G_{\mathrm{DT}}$ or $\theta_{\mathrm{DT}}$ (Student's $t$ test: $t_{\min }=4.9$, d.f. $=12, P<0.001$ ). Although these latter comparisons could be biased by the small sample size of RG88 and GU85, this result may indicate that the genetic isolation of the populations of $P$. grasslei is mostly the result of bathymetric and edaphic gaps between ridges rather than the geographical distance itself. This is clearly shown by the percentages of the alleles which display a significant value of $F_{\mathrm{ST}}$ from each set of populations grouped according to the

Fig. 3 Relationship between the number of migrants exchanged between two populations per generation $(\mathrm{Nm})$ and the geographical distance separating their corresponding collection sites at $13^{\circ} \mathrm{N} / \mathrm{EPR}$ for both Alvinella pompejana (a) and Alvinella caudata (b) and, along the East Pacific Rise for Paralvinella grasslei (c). Nm is estimated (1) by Slatkin's 'private allele' method (empty diamond: Slatkin, 1985), and (2) by Wright's formula (Wright, 1965) using $F_{\text {sT }}$ derived from $G_{\mathrm{ST}}$ (black diamond: Nei, 1977) and $\theta$ coancestry (empty circle: Weir \& Cockerham, 1984). Bars represent the standard deviation obtained when more than two populations are separated by the same geographical distance. 
Table $5 F_{\text {ST }}$ values estimated among distinct segments of the East Pacific Rise $\left(G_{\mathrm{DR}}\right.$ and $\left.\theta_{\mathrm{DR}}\right)$ and among sites within the $13^{\circ} \mathrm{N} / \mathrm{EPR}$ segment $\left(G_{\mathrm{DS}}\right.$ and $\left.\theta_{\mathrm{DS}}\right)$ for Alvinella pompejana

\begin{tabular}{llcll}
\hline Locus & \multicolumn{1}{c}{$G_{\mathrm{DS}}$} & $\theta_{\mathrm{DS}} \pm \mathrm{SD}$ & \multicolumn{1}{c}{$G_{\mathrm{DR}}$} & \multicolumn{1}{c}{$\theta_{\mathrm{DR}} \pm \mathrm{SD}$} \\
\hline Aat -1 & - & - & 0.020 & $0.005 \pm 0.005$ \\
Acoh-1 & 0.051 & $0.016 \pm 0.020$ & 0.044 & $0.011 \pm 0.016$ \\
Acoh -2 & $0.507^{* * *}$ & $0.289 \pm 0.162^{* *}$ & $0.461^{* * *}$ & $0.299 \pm 0.124^{* * *}$ \\
Acp & 0.025 & $-0.007 \pm 0.009$ & 0.021 & $-0.008 \pm 0.007$ \\
Ak & 0.007 & $-0.025 \pm 0.012$ & 0.007 & $-0.026 \pm 0.012$ \\
Cap-2 & 0.014 & $-0.009 \pm 0.005$ & 0.019 & $-0.005 \pm 0.007$ \\
Fumh & 0.027 & $0.016 \pm 0.030$ & 0.022 & $0.011 \pm 0.025$ \\
a Gpdh & 0.060 & $0.031 \pm 0.031$ & 0.054 & $0.030 \pm 0.028^{*}$ \\
Gpi & 0.051 & $0.032 \pm 0.035$ & 0.055 & $0.033 \pm 0.035$ \\
Idh-1 & 0.019 & $-0.014 \pm 0.005$ & 0.029 & $-0.004 \pm 0.015$ \\
Mdh-1 & $0.069^{*}$ & $0.024 \pm 0.043$ & $0.079^{*}$ & $0.034 \pm 0.042$ \\
Mpi & $0.106^{* * *}$ & $0.084 \pm 0.028^{* * *}$ & $0.100^{* * *}$ & $0.076 \pm 0.024^{* * *}$ \\
Pgm & 0.052 & $0.018 \pm 0.034$ & 0.049 & $0.019 \pm 0.025$ \\
Mean & $0.082^{* * *}$ & $0.045^{* * *}$ & $0.075^{* * *}$ & $0.042^{* * *}$ \\
SD & 0.039 & 0.027 & 0.033 & 0.025 \\
Mean\& & $0.044^{* * *}$ & $0.020^{* * *}$ & $0.042^{* * *}$ & $0.019^{* * *}$ \\
SD $\$$ & 0.009 & 0.009 & 0.008 & 0.008 \\
\hline
\end{tabular}

Significance levels were determined according to Workman and Niswander (1970) for single values of $F_{\mathrm{ST}}$ and by $t$-tests for jackknife estimates (over populations: $\theta_{\mathrm{DS}}$ and $\theta_{\mathrm{DR}}$ and over loci: mean). Table-wide significance levels.

${ }^{*} P \leqslant 0.05,{ }^{* *} P \leqslant 0.01,{ }^{* * *} P \leqslant 0.001$.

$\S$ Jackknife estimates without the Acoh-2 locus.

Table $6 F_{\text {ST }}$ values estimated among distinct segments of the East Pacific Rise $\left(G_{\mathrm{DR}}\right.$ and $\left.\theta_{\mathrm{DR}}\right)$ and among sites within the $13^{\circ} \mathrm{N} / \mathrm{EPR}$ segment $\left(G_{\mathrm{DS}}\right.$ and $\left.\theta_{\mathrm{DS}}\right)$ for Alvinella caudata

\begin{tabular}{llcll}
\hline Locus & \multicolumn{1}{c}{$G_{\mathrm{DS}}$} & \multicolumn{1}{c}{$\theta_{\mathrm{DS}} \pm \mathrm{SD}$} & \multicolumn{1}{c}{$G_{\mathrm{DR}}$} & \multicolumn{1}{c}{$\theta_{\mathrm{DR}} \pm \mathrm{SD}$} \\
\hline Aat -1 & 0.021 & $0.000 \pm 0.009$ & 0.019 & $-0.001 \pm 0.008$ \\
Acoh-1 & 0.038 & $0.043 \pm 0.036^{* *}$ & $0.110^{* * *}$ & $0.175 \pm 0.087^{* * *}$ \\
Acoh-2 & 0.012 & $-0.007 \pm 0.010$ & 0.021 & $0.002 \pm 0.014$ \\
Acp & 0.043 & $-0.007 \pm 0.009$ & 0.042 & $0.024 \pm 0.014^{* * *}$ \\
Cap-2 & 0.026 & $0.002 \pm 0.016$ & 0.028 & $0.006 \pm 0.015$ \\
Fumh & 0.014 & $-0.002 \pm 0.009$ & 0.015 & $-0.001 \pm 0.009$ \\
$\alpha$ Gpdh & $0.056^{*}$ & $0.055 \pm 0.052^{* *}$ & $0.057^{*}$ & $0.053 \pm 0.045^{* *}$ \\
Gpi & 0.012 & $0.000 \pm 0.010$ & 0.010 & $-0.005 \pm 0.007$ \\
Idh-1 & 0.006 & $-0.007 \pm 0.010$ & $0.058^{*}$ & $0.062 \pm 0.078^{*}$ \\
Mdh-1 & 0.005 & $-0.017 \pm 0.003$ & 0.008 & $-0.012 \pm 0.007$ \\
Mpi & $0.044^{*}$ & $0.015 \pm 0.022^{*}$ & $0.091^{* * *}$ & $0.082 \pm 0.074^{* *}$ \\
Pgm & 0.053 & $0.035 \pm 0.038^{*}$ & 0.046 & $0.025 \pm 0.030^{*}$ \\
Mean & $0.029^{* * *}$ & $0.011^{* * *}$ & $0.042^{* * *}$ & $0.031^{* * *}$ \\
SD & 0.005 & 0.006 & 0.009 & 0.012 \\
Mean§ & $0.027^{* * *}$ & $0.010^{* * *}$ & $0.036^{* * *}$ & $0.022^{* * *}$ \\
SD $\$$ & 0.006 & 0.006 & 0.008 & 0.010 \\
\hline
\end{tabular}

Significance levels were determined according to Workman \& Niswander $(1970)$ for single values of $F_{\mathrm{ST}}$ and by $t$-tests for jackknife estimates (over populations: $\theta_{\mathrm{DS}}$ and $\theta_{\mathrm{DR}}$ and over loci: mean). Table-wide significance levels.

${ }^{*} P \leqslant 0.05,{ }^{* *} P \leqslant 0.01,{ }^{* * *} P \leqslant 0.001$.

$\S$ Jackknife estimates without the Acoh-1 locus. 
Table $7 F_{\mathrm{ST}}$ values estimated among distinct ridges $\left(G_{\mathrm{DT}}\right.$ and $\left.\theta_{\mathrm{DT}}\right)$, among distinct segments of the East Pacific Rise $\left(G_{\mathrm{DR}}\right.$ and $\left.\theta_{\mathrm{DR}}\right)$ and among sites within the $13^{\circ} \mathrm{N} / \mathrm{EPR}$ segment $\left(G_{\mathrm{DS}}\right.$ and $\left.\theta_{\mathrm{DS}}\right)$ for Paralvinella grassle $i$

\begin{tabular}{lllllll}
\hline Locus & \multicolumn{1}{c}{$G_{\mathrm{DS}}$} & \multicolumn{1}{c}{$\theta_{\mathrm{DS}} \pm \mathrm{SD}$} & \multicolumn{1}{c}{$G_{\mathrm{DR}}$} & $\theta_{\mathrm{DR}} \pm \mathrm{SD}$ & $G_{\mathrm{DT}}$ & $\theta_{\mathrm{DT}} \pm \mathrm{SD}$ \\
\hline Aat -1 & 0.016 & $0.012 \pm 0.022$ & 0.023 & $0.012 \pm 0.009^{* * *}$ & 0.030 & $0.011 \pm 0.008^{* * *}$ \\
Acoh-1 & 0.046 & $0.047 \pm 0.022^{* * *}$ & 0.051 & $0.041 \pm 0.029^{* * *}$ & 0.070 & $0.044 \pm 0.024^{* * *}$ \\
Acoh-2 & $0.106^{* * *}$ & $0.124 \pm 0.135^{* *}$ & 0.076 & $0.042 \pm 0.056^{*}$ & 0.083 & $0.051 \pm 0.038^{* * *}$ \\
Acp & 0.022 & $0.007 \pm 0.030$ & 0.031 & $0.021 \pm 0.016^{* * *}$ & $0.116^{*}$ & $0.067 \pm 0.044^{* * *}$ \\
Cap-2 & 0.047 & $0.042 \pm 0.035^{* * *}$ & 0.035 & $0.019 \pm 0.020^{* *}$ & $0.177^{* * *}$ & $0.091 \pm 0.088^{* *}$ \\
Dia-3 & 0.019 & $0.014 \pm 0.017^{*}$ & 0.013 & $0.004 \pm 0.014$ & $0.128^{* * *}$ & $0.083 \pm 0.085^{* *}$ \\
Gpi & 0.013 & $0.007 \pm 0.015$ & 0.011 & $-0.002 \pm 0.005$ & 0.044 & $0.008 \pm 0.013$ \\
Hk-1 & $0.038^{*}$ & $0.032 \pm 0.053$ & $0.066^{* * *}$ & $0.073 \pm 0.064^{* *}$ & $0.065^{* *}$ & $0.064 \pm 0.055^{* *}$ \\
Idh-1 & 0.008 & $-0.008 \pm 0.005$ & 0.019 & $0.009 \pm 0.023$ & 0.034 & $0.011 \pm 0.022$ \\
Mdh-1 & 0.009 & $-0.008 \pm 0.010$ & 0.020 & $0.016 \pm 0.018^{* *}$ & 0.028 & $0.013 \pm 0.012^{* *}$ \\
Mdh-2 & 0.006 & $-0.014 \pm 0.009$ & 0.006 & $-0.014 \pm 0.002$ & 0.009 & $-0.015 \pm 0.004$ \\
Mpi & 0.014 & $-0.003 \pm 0.016$ & 0.016 & $0.001 \pm 0.005$ & 0.064 & $0.018 \pm 0.023^{*}$ \\
Pgm & 0.002 & $-0.018 \pm 0.003$ & 0.006 & $-0.009 \pm 0.008$ & 0.051 & $0.006 \pm 0.020$ \\
Mean & $0.027^{* * *}$ & $0.017^{* * *}$ & $0.029^{* * *}$ & $0.017^{* * *}$ & $0.069^{* * *}$ & $0.037^{* * *}$ \\
SD & 0.008 & 0.011 & 0.006 & 0.007 & 0.013 & 0.010 \\
Mean§ & $0.020^{* * *}$ & $0.009^{* *}$ & $0.025^{* * *}$ & $0.014^{* * *}$ & $0.068^{* * *}$ & $0.035^{* * *}$ \\
SD & 0.005 & 0.007 & 0.005 & 0.007 & 0.014 & 0.010 \\
\hline
\end{tabular}

Significance levels were determined according to Workman and Niswander (1970) for single values of $F_{\mathrm{ST}}$ and by $t$-tests for jackknife estimates (over populations: $\theta_{\mathrm{DS}}, \theta_{\mathrm{DR}}$ and $\theta_{\mathrm{DT}}$ and over loci: mean). Table-wide significance levels. ${ }^{*} P \leqslant 0.05$, ${ }^{* *} P \leqslant 0.01,{ }^{* * *} P \leqslant 0.001$. § Jackknife estimates without the Acoh-2 locus.

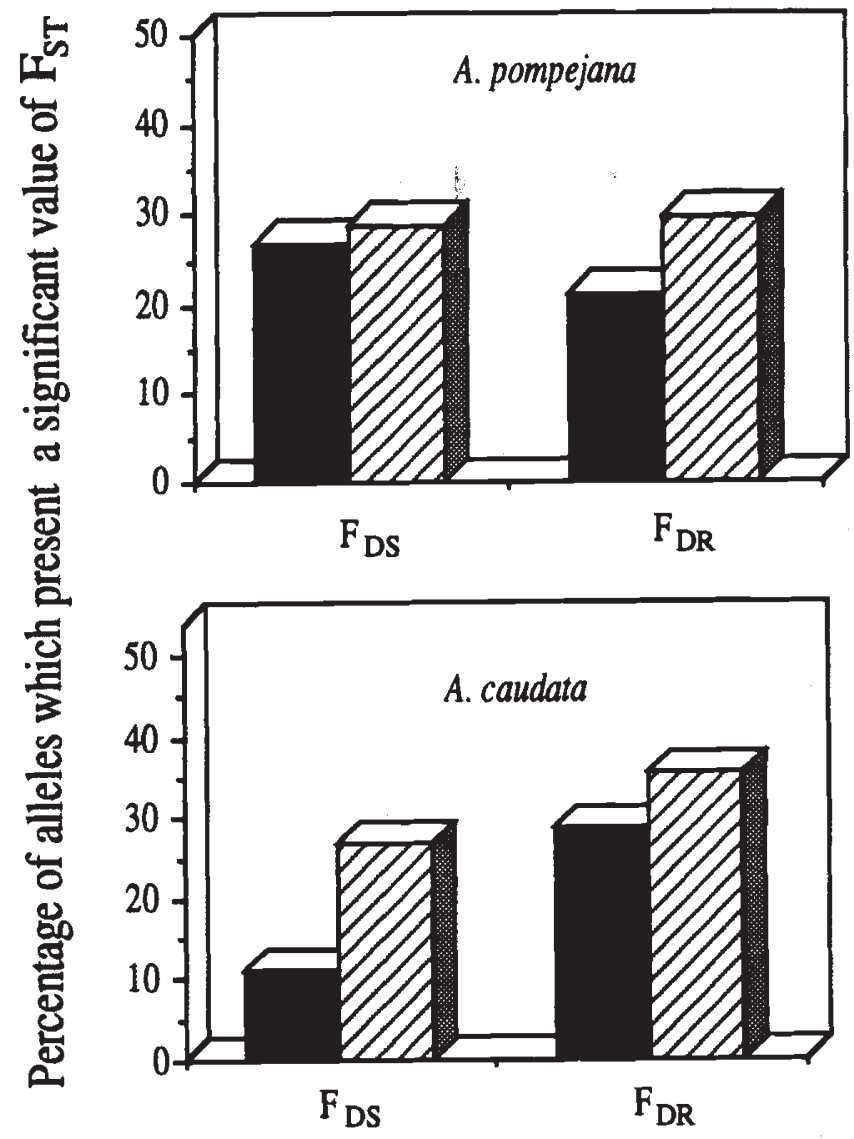

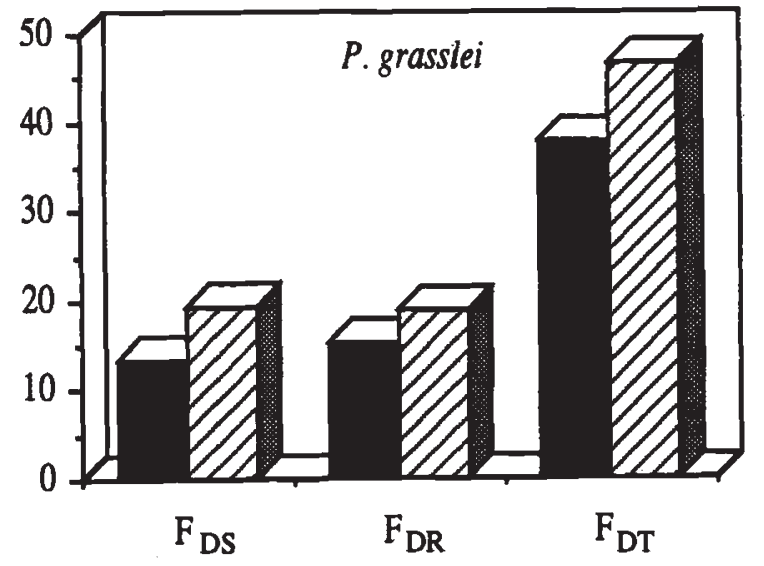

Fig. 4 Histograms showing the percentage of alleles which display a significant value of $F_{\text {ST }}$ across alvinellid populations nested at distinct spatial scales according to Workman \& Niswander (1970) at 5 per cent (scratched bars) and 1 per cent (black bars) levels of significance.

(c) 1995 The Genetical Society of Great Britain, Heredity, 74, 4. 
spatial distribution of vents (single-allele $F_{\mathrm{ST}}$ : $\chi^{2}=2 N . F_{\text {ST }}$, Workman \& Niswander, 1970 $\rangle\langle$ Fig. 4).

\section{Discussion}

\section{Evidence of repeated founder effects in the Alvinella populations}

The genetic variability of the deep-sea hydrothermal alvinellid polychaetes is high, especially for $P$. grasslei $\left(P_{95 \%}=63.5\right.$ per cent, $\left.H_{\mathrm{o}}=0.235\right)$ in comparison to other invertebrates (Hartl, 1988). This is mainly because of the presence or the absence of numerous alleles whose frequency does not exceed 0.1 . This genetic characteristic of alvinellids does not fit the hypothesis that repeated extinctions in populations of hydrothermal vent organisms act to reduce polymorphism, as suggested by Bucklin (1988) to explain the low genetic variability of the deep-sea hydrothermal giant tube-worm Riftia pachyptila. Conversely, our values fit well with previous genetic studies conducted on shallow-water polychaetes (Grassle \& Grassle, 1976; Nicklas \& Hoffman, 1979; Bristow \& Vadas, 1991) which reported percentages of polymorphic loci varying from 50 to 70 per cent and heterozygosities which often exceed 0.15 . These results are also close to those reported for deep-sea nonhydrothermal organisms (Ayala et al., 1975; Siebenaller, 1978) and contradict the hypothesis that both the stability of the environmental conditions (Gooch \& Schopf, 1972) and the high genetic exchanges within nonlimited populations (Soulé, 1976) are responsible for the apparent high genetic variability of these nonhydrothermal deep-sea organisms.

Surprisingly, levels of genetic diversity vary according to the alvinellid genera. We noticed that both the percentage of polymorphic loci and the observed heterozygosity of $P$. grassle $i$ are about twice that of the two Alvinella species, and correspond to levels usually found in other paralvinellid species (Jollivet, 1993; Tunnicliffe et al., 1993).

At least three hypotheses could explain this difference: (1) the two Alvinella species bear epibiotic bacteria which could favour a low genetic diversity through coevolutionary processes, (2) Alvinella spp. live inside a tube and are able to control their microenvironment, (3) genetic exchanges across populations of Alvinella spp. may be less important than those across populations of Paralvinella spp. because the Alvinella species are sedentary and less opportunistic than the other Paralvinella species.

The first hypothesis is attractive. The Alvinella species as well as the other deep-sea hydrothermal vent symbiont-bearing species must deal with both the chemoautotrophic symbionts' requirements and their own. As a consequence, such an association may have reduced the host genome to a highly specialized allelic pool. Allozyme studies conducted on deep-sea hydrothermal vent symbiont-bearing species (Grassle, 1985; Bucklin, 1988; Denis et al., 1993; Vrijenhoek et al., 1993) have shown that these organisms display a lower genetic diversity than other endemic vent taxa such as the paralvinellid polychaetes (Jollivet, 1993; Tunnicliffe et al., 1993), the amphipod Ventiella sulfuris (France et al., 1992) or some of the limpet species (Vrijenhoek, pers. com.). However, shallowwater species which exhibit endosymbionts such as the lucinids display very high levels of polymorphism (Dwiono et al., 1989).

The second hypothesis assumes that the Alvinella species as well as the bivalves or the giant-tube worms which live inside shells or organic tubes are able to control their microenvironment by exhibiting thermoregulatory behaviour (Chevaldonné et al., 1991). In contrast, amphipods and paralvinellid species which are able to move but lack such a protective test have to experience a wider range of environmental conditions which may favour the heterozygote genotypes because of their less energy-demanding maintenance (Koehn \& Bayne, 1989).

The third hypothesis is possibly the best explanation for the maintenance of high levels of polymorphism for the paralvinellid species. Unlike the Alvinella species, in situ observations demonstrate that paralvinellid species crawl over the walls of hydrothermal chimneys in order to feed on deposits (Chevaldonné \& Jollivet, 1993) and are able to move from vent to vent using crabs as a vector (Tunnicliffe \& Jensen, 1987). Such a phoretic process could increase genetic exchanges across populations, and may avoid bottleneck effects in local populations which are often responsible for reducing polymorphism, as was previously found for subterranean organisms (Nevo et al., 1974).

\section{Genetic structure of alvinellid populations on a microgeographical scale}

Genetic structure in marine sedentary invertebrates mostly depends on their ability to disperse and on the heterogeneous conditions that the marine environment provides. The alvinellid polychaetes exhibit a great genetic variation between populations on a microgeographical scale. Such a differentiation mostly arises from the presence or absence of numerous alleles, the frequency of the most common alleles being unaffected. Exposure to high levels of radioactivity may cause such a pattern by increasing the mutation rate as well as the frequency of null alleles, which may account for the systematic heterozygote deficiency 
found at many loci. However, no null homozygotes have been observed so far. Nevertheless, the level of differentiation existing between alvinellid populations seems to confirm the low dispersal ability of alvinellids suggested by previous studies conducted on their reproductive system and development (Desbruyères \& Laubier, 1986; McHugh, 1989; Zal et al., 1994). Indeed, the tendency towards heterozygote deficiencies in nearly all populations compared with Hardy-Weinberg expectations supports neither a Wahlund effect nor selective mortality in larvae before settlement, as is commonly observed in marine organisms exhibiting a long planktotrophic phase (Zouros \& Foltz, 1984) but not in organisms having direct development such as the gastropod Bembicium vittatum (Johnson \& Black, 1991). Some recent studies have also reported chaotic genetic variabilities among populations at micro- and macro-spatial scales for organisms which do have planktotrophic larvae (Johnson \& Black, 1982; Watts et al., 1990; Planes et al., 1994). Such variability has been explained by peculiar hydrodynamic conditions or selection which may vary from habitat to habitat. However, extinction/ recolonization could also explain such a differentiation when the environment is unstable.

Wright (1965) claimed that extinction and recolonization alone would enhance genetic differentiation in local populations because the number of individuals which colonize a suitable habitat is lower than the effective size of a local population. In situ observations accumulated over the last decade on hydrothermal vent communities have provided evidence for the rapid evolution of vents. The localized cessation of the hydrothermal activity causes strong bottleneck effects in populations of sessile symbiont-bearing species (Hessler et al., 1988; Jollivet, 1993). There are two different models of the way in which colonists might be chosen to found new populations ('migrant pool' and 'propagule pool' models), which have been shown to have very different effects on the rate and the extent of the genetic differentiation of local populations (McCauley, 1991). For alvinellid polychaetes, most of the migrants have to colonize vacant habitats because of the short duration of vents and colonists at a particular vacant site must represent a mix of individuals drawn from one or a few nearby populations ('propagule pool' model). Indeed, Jollivet (1993) reported that the extinction of a vent seems to be associated with the emergence of a new one in its close vicinity, allowing propagules from the dying vent to colonize this vacant habitat. Such a colonization process may result in increasing genetic differentiation in populations and, as long as the number of colonists $K$ is small relative to $2 \mathrm{Nm}$, may produce the genetic structure we observed (i.e. presence/absence of the less frequent alleles but less variation in the frequency of the most common alleles).

However, the genetic differentiation between populations could be minimized by the phoretic ability of some of the alvinellid species. Indeed, in situ observations have shown that the deep-sea hydrothermal crabs Bythograea thermydron and Cyanagraea praedator, which prey on $P$. grasslei and the Alvinella species, respectively, move from vent to vent as soon as the hydrothermal activity ceases at a location. As $B$. thermydron is about 10 times more numerous and more opportunistic than its counterpart $C$. praedator (Fustec et al., 1987), we would expect exchanges across the populations of $P$. grasslei to be more important than those across the Alvinella species, as we indeed found.

\section{Genetic differentiation of alvinellid populations along the East Pacific Rise}

If repeated founder effects can explain the great genetic differentiation of the Alvinella populations on a microgeographical scale, we cannot explain why the level of differentiation increases so little with geographical distance. At the axis of oceanic ridges, currents are canalized in the central graben and could polarize the larval flux along the rift. However, the average current speeds obtained so far may not be sufficient to support long-range dispersal for the alvinellids (Lonsdale, 1977; A. Vangriesheim, pers. comm.). To explain genetic homogeneity across disjunct populations separated by at least $1000 \mathrm{~km}$, we propose that most of the enzyme loci are exposed to uniform balancing selection mostly driven by the rapid aerobic-anaerobic alternation of the vent conditions, and the outliers we detected using Dixon's test could be the only loci to use in estimating gene flow. Indeed, the hydrothermal environment is conservative and produces a habitat which does not vary spatially along ridges, as was ascertained by comparisons in fluid chemistry between localities (Edmond et al., 1982; Michard et al., 1984). The aerobic-anaerobic alternation of the vent conditions at a location may also be one of the causes for the consistency of apparent heterozygote deficiencies at many loci which are difficult to reconcile with stochastic events. Such an interpretation is somewhat unusual for marine invertebrates for which selection seems to act mostly to produce genetic differences in populations (Johnson \& Black, 1991). However, Karl \& Avise (1992) argued that allozymes could be exposed to balancing selection to provide an apparent genetic homogeneity in oyster populations in contrast to the results of mtDNA or genomic DNA restriction analyses. Thermostability of allozymes of the AAT and PGM systems vary markedly from genotype to geno- 
type within and between alvinellid species (Jollivet, 1993). Such a differential sensitivity of allozymes to temperature may be a genetic response to the temporal instability of the vent emissions and may explain the high levels of polymorphism as well as the genetic homogeneity found among the alvinellid populations along the East Pacific Rise.

\section{Acknowledgements}

We thank the captains and the crew of the N.O Le Nadir and the R. V. Atlantis, the Nautile and the Alvin pilots and their support crew, without whose expertise and assistance this work would not have been possible. We are indebted to J. F. Grassle, chief scientist of the Guaymas Basin 1985 cruise, A.-M. Alayse, chief scientist of the Hydronaut 1987 cruise, J. J. Childress, chief scientist of the Galapagos Rift 1988 cruise, and R. R. Lutz and R. C. Vrijenhoek, co-chief scientists of the MMVT 1990 cruise, who sampled and stored the biological material and gave us their agreement to analyse it. We also thank A. Solé Cava, L. and D. Dixon, A. Rogers, E. and A. Southward as well as the two anonymous reviewers for their critical review of the manuscript and their useful comments. This work was supported by IFREMER and the Fondation des Amis de la Science.

\section{References}

AVISE, J. C. 1994. Molecular Markers, Natural History and Evolution. Chapman and Hall, New York, London.

AYALA, F. J., VALENTINE, J. W., HEDGECOCK, D. AND BARR, L. G. 1975. Deep-sea asteroids: high genetic variability in a stable environment. Evolution, 29, 203-212.

BLACK, M. B. 1991. Genetic (Allozyme) Variation in Vestimentifera (Ridgeia spp.) from Hydrothermal Vents of the Juan de Fuca Ridge (Northeast Pacific Ocean). M. Sc. Thesis, University of Victoria, Canada.

BONHOMME, F., BELKHIR, K., MATHIEU, E. AND ROUX, M. 1993. GENETIX - Logiciel d'analyse des données en génétique des populations, version 0.0. Université des Sciences et Techniques du Languedoc, Montpellier, France.

BRISTOW, G. A. AND VADAS, S. R. L. 1991. Genetic variability in bloodworm (Glycera dibranchiata) populations in the Gulf of Maine. Mar, Biol., 109, 311-319.

BROWN, A. H. D. 1970. The estimation of Wright's fixation index from genotypic frequencies. Genetica, 41, 399-406.

BUCKLIN, A. 1988. Allozymic variability of Riftia pachyptila populations from the Galapagos Rift and $21^{\circ} \mathrm{N}$ hydrothermal vents. Deep-Sea Res., 35, 1759-1768.

CHERRY, R., DESBRUYERES, D., HEYRAUD, M. AND NOLAN, C. 1992. High levels of natural radioactivity in hydrothermal vent polychaetes. C. r. Acad. Sci. Paris, sér. III, 315, 21-26.

CHEVALDONNE, P., DESBRUYERES, D. AND CHILDRESS, J. J. 1992 ... and some even hotter. Nature, 359, 593-594.
CHEVALDONNE, P., DESBRUYÈRES, D. AND LE HAITRE, M. 1991. Time-series of temperature from three deep-sea hydrothermal vent sites. Deep-Sea Res., 38, 1417-1430.

CHEVALDONNÉ, P. AND JOLLIVET, D. 1993. Videoscopic study of deep-sea hydrothermal vent alvinellid polychaete populations: biomass estimation and behaviour. Mar. Ecol. Prog. Ser., 95, 251-262.

DENIS, F., JOLLIVET, D. AND MORAGA, D. 1993. Genetic separation of two allopatric populations of hydrothermal snails Alviniconcha spp. (Gastropoda) from two Southwestern Pacific back-arc basins. Biochem. Syst. Ecol., 21, 431-440.

DESBRUYĖRES, D. AND LAUBIER, L. 1980. Alvinella pompejana gen. sp. nov., aberrant Ampharetidae from the East Pacific Rise hydrothermal vents. Oceanol. Acta, 3, 267-274.

DESBRUYEERES, D. AND LAUBIER, L. 1986. Les Alvinellidae, une famille nouvelle d'annélides polychètes inféodées aux sources hydrothermales sous-marines: systématique, biologie et écologie. Can. J. Zool., 64, 2227-2245.

DWIONO, S. A. P., MORAGA, D., LE PENNEC, M. AND MONNAT, J. 1989. Genetic variability of the Lucinidae: Loripes lucinalis, Lucinella divaricata and Lucinoma borealis minor (Molluca: Bivalvia) from Brittany, France. Biochem. Syst. Ecol., 17, 463-468.

EDMOND, J. M., VON DAMM, K. L., MCDUFF, R. E. AND MEASURES, C. I 1982. Chemistry of hot springs on the East Pacific Rise and their effluent dispersal. Nature, 297, 187-191.

FRANCE, S. C., HESSLER, R. R. AND VRIJENHOEK, R. C. 1992. Genetic differentiation between spatially-disjunct populations of the deep-sea, hydrothermal vent-endemic amphipod Ventiella sulfuris. Mar. Biol., 114, 551-559.

FUSTEC, A., DESBRUYERES, D. AND JUNIPER, S. K. 1987. Deep-sea hydrothermal vent communities at $13^{\circ} \mathrm{N}$ on the East Pacific Rise: microdistribution and temporal variations. Biol. Oceanogr., 4, 121-164.

GAILL, F., HALPERN, S., QUINTANA, C. AND DESBRUYERES, D. 1984 Présence intracellulaire d'arsenic et de zinc associés au soufre chez une Polychète des sources hydrothermales (Alvinella pompejana). C. r. Acad. Sci. Paris, sér. III, 298, 331-336.

GOOCH, J. L. AND SCHOPF, T. J. M. 1972. Genetic variability in the deep-sea: relation to environmental variability. Evolution, 26, 545-552.

GRASSLE. J. P. 1985. Genetic differentiation in populations of hydrothermal vent mussels (Bathymodiolus thermophilus) from the Galapagos Rift and $13^{\circ} \mathrm{N}$ on the East Pacific Rise. Biol. Soc. Wash. Bull., 6, 429-442.

GRASSLE, J. P. AND GRASSLE, J. F. 1976. Sibling species in the marine pollution indicator Capitella (Polychaeta). Science, 192, 567-569.

HARRIS, H. AND HOPKINSON, D. A. 1976. Handbook of Enzyme Electrophoresis in Human Genetics. North-Holland Publishing Company, Amsterdam.

HARTL. D. L. 1988. A Primer of Population Genetics, 2nd edn Sinauer Associates, Sunderland, MA.

HAYMON, R. M., FORNARI, D. J., VON DAMM, K. L., LILLEY, M. D., PERFIT, M. R., EDMOND, J, M., SHANKS, W. C., LUTZ, R. A., GREBMEIER, J. M., CARBOTTE, S., WRIGHT, D., MCLAUGHLIN, E., SMITH, M., BEEDLE, N. AND OLSON, E. 1993. Volcanic eruption of the mid-ocean 
ridge along the East Pacific Rise crest at $9^{\circ} 4552^{\prime} \mathrm{N}$ : direct submersible observations of sea-floor phenomena associated with an eruption event in April, 1991. Earth Planet. Sci. Lett., 119, 85-101.

HESSLER, R. R. AND LONSDALE, P. F. 1991. Biogeography of Mariana Trough hydrothermal vent communities. DeepSea Res., 38, 185-199.

HESSLER, R. R., SMITHEY, W. M., BOUDRIAS, M. A., KELLER, C. H., LUTZ, R. A. AND ChILDRESS, J. J. 1988. Temporal change in megafauna at the Rose Garden hydrothermal vent. DeepSea Res., 35, 1681-1710.

HOCHBERG, Y. 1988. A sharper Bonferroni procedure for multiple tests of significance. Biometrika, 75, 800-802.

JOHNSON, M. S. AND BLACK, R. 1982. Chaotic genetic patchiness in an intertidal limpet, Siphonaria spp. Mar. Biol., 70, 157-164.

JOHNSON, M. S. AND BLACK, R. 1991. Genetic subdivision of the intertidal snail Bembicium vittatum (Gasteropoda: Littorinidae) varies with habitat in the Houtman Abrolhos Islands, Western Australia. Heredity, 67, 205-213.

JOLLIVET, D. 1993. Distribution et évolution de la faune associée aux sources hydrothermales profondes à $13^{\circ} \mathrm{N}$ sur la dorsale du Pacifique oriental: le cas particulier des polychètes Alvinellidae. Thèse de Doctorat N. R., Université de Bretagne Occidentale, France.

KARL, S. A. AND AVISE, J. C. 1992. Balancing selection at allozyme loci in oysters: implications from nuclear RFLPs. Science, 256, 100-102.

KIMURA, M. AND WEISS, G. H. 1964 . The stepping stone model of population structure and the decrease of genetic correlation with distance. Genetics, 49, 561-576.

KOEHN, R. K. AND BAYNE, B. L. 1989. Towards a physiological and genetical understanding of the energetics of the stress response. Biol. J. Linn. Soc., 37, 157-171.

LALOU, C. 1991. Deep-sea hydrothermal venting: a recently discovered marine system. J. Mar. Syst., 1, 403-440.

LEVENE, H. 1949. On a matching problem arising in genetics. Ann. Math. Stat, 20, 91-94.

LONSDALE, P. F. 1977. Clustering of suspension-feeding macrobenthos near abyssal hydrothermal vents at oceanic spreading centers. Deep-Sea Res., 24, 857-863.

MANLY, в. F. J. 1985. The Statistics of Natural Selection on Animal Populations. Chapman and Hall, London.

McCAULEY, D. E. 1991. Genetic consequences of local population extinction and recolonization. Trends Ecol. Evol., 6, $5-8$.

McHUGH, D. 1989. Population structure and reproductive biology of two sympatric hydrothermal vent polychaetes, Paralvinella pandorae and Paralvinella palmiformis. Mar. Biol., 103, 95-106.

MICHARD, G., ALBARÈDE, F., MICHARD, A., MINSTER, J., CHARLOU, J. L. AND TAN, N. 1984 . Chemistry of solutions from the $13^{\circ} \mathrm{N}$ East Pacific Rise hydrothermal site. Earth Planet. Sci. Lett., 67, 297-307.

NEI, M. 1977. F-statistics and analysis of gene diversity in subdivided populations. Ann. Hum. Genet., 41, 225-233.

NEVO, E., KIM, Y. J., SHAW, C. R. AND THAELER, C. S. 1974. Genetic variation, selection, and speciation in Thomomys talpoides pocket gophers. Evolution, 28, 1-23.
NICKLAS, N. L. AND hOFFMAN, R. J. 1979. Genetic similarity between two morphologically similar species of polychaetes. Mar. Biol., 52, 53-59.

PASTEUR, N., PASTEUR, G., BONHOMME, F., CATALAN, J. AND BRITTON. Davidian, J. 1987. Manuel Technique de Génétique par Électrophorèse des Protéines. Lavoisier, Paris.

PLANES, S., BORSA, P., GALZIN, R. AND вONHOMME, F. 1994. Geographical structure and gene flow in the manini (convict surgeonfish, Acanthurus triostegus) in the southcentral Pacific. In: Beaumont, A. R. (ed.) Genetics and Evolution of Aquatic Organisms, pp. 113-121. Chapman and Hall, London.

SIEBENAlleR, J. F. 1978. Genetic variation in deep-sea invertebrate populations: the bathyal gastropod Bathybembix bairdii. Mar. Biol., 47, 265-275.

SLATKIN, M. 1985. Rare alleles as indicators of gene flow. Evolution, 39, 53-65.

SLATKIN, M. AND BARTON, N. H. 1989. A comparison of three indirect methods for estimating average levels of gene flow. Evolution, 43, 1349-1368.

SOKAL, R. R. AND ROHLF, F. J. 1981. Biometry, 2nd edn. Freeman and Co., San Francisco.

SOULÉ, M. 1976. Allozyme variation: its determinant in space and time. In: Ayala, F. J. (ed.) Molecular Evolution, pp. 60-76. Sinauer Associates, Sunderland, MA.

SWOFFORD, D. L. AND SELANDER, R. B. 1989. BIOSYS-1. A computer program for the analysis of allelic variation in population genetics and biochemical systematics. Release 1.7. University of Illinois, Urbana, IL.

TUNNICLIFFE, v. 1988. Biogeography and evolution of hydrothermal-vent fauna in the eastern Pacific Ocean. Proc. $R$. Soc. B, 233, 347-366.

TUNNICLIFFE, v. 1991. The biology of hydrothermal vents: Ecology and evolution. Oceanogr. Mar. Biol. Ann. Rev., 29, 319-407.

TUNNICLIFFE, V., DESBRUYERES, D., JOLLIVET, D. AND LAUBIER, L. 1993. Systematic and ecological characteristics of Paralvinella sulfincola Desbruyères and Laubier, a new polychaete (family Alvinellidae) from northeast Pacific hydrothermal vents. Can. J. Zool., 71, 286-297.

TUNNICLIFFE, v. AND JENSEN, R. G. 1987. Distribution and behavior of the spider crab Macroregonia macrochira Sakai (Brachyura) around the hydrothermal vents of the northeast Pacific. Can. J. Zool., 65, 2443-2449.

vitHAYASAI, c. 1973. Exact critical values of the Hardy-Weinberg test statistic for two alleles. Commun. Stat., 1, 229-242.

VRIJENHOEK, R. C., LUTZ, R. A., CRADDOCK, C., BLACK, M. B., KARL, S. HOEH, W. R. AND GUSTAFSON, R. 1993. Gene flow and speciation in deep-sea hydrothermal vent organisms. In: Catzeflis, F. M. (ed.) Evolution 93, p. 484. Fourth Congress of the European Society for Evolutionary Biology, Montpellier, France.

WATREMEZ, P. AND KERVEVAN, c. 1990. Origine des variations de l'activité hydrothermale: premiers éléments de réponse d'un modèle numérique simple. C. r. Acad. Sci. Paris, sér. II, 311, 153-158.

WATTS, R. J., JOHNSON, M. S. AND BLACK, R. 1990. Effects of recruitment on genetic patchiness in the urchin Echino- 
metra mathaei in Western Australia. Mar. Biol., 105, 145-151.

WEIR, B. S. 1990. Intraspecific differentiation. In: Hillis, D. M. and Moritz, C. (eds) Molecular Systematics, pp. 373-410. Sinauer Associates, Sunderland, MA.

WEIR, B. S. AND COCKERHAM, C. C. 1984 . Estimating $F$-statistics for the analysis of population structure. Evolution, 38, 1358-1370.

WORKMAN, P. L. AND NISWANDER, J. D. 1970. Population studies on southwestern Indian tribes. II. Local genetic differentiation in the Papago. Am. J. Hum. Genet., 22, 24-49.
WRIGHT, s. 1965. The interpretation of population structure by $F$-statistics with special regard to systems of mating. Evolution, 19, 395-420.

ZAL, F., DESBRUYËRES, D. AND JOUIN-TOULMOND, C. 1994. Sexual dimorphism in Paralvinella grasslei, a polychaete annelid from deep-sea hydrothermal vents. C. r. Acad. Sci. Paris, Life sciences, 317, 42-48.

zouRos, E. AND FolTz, D. w. 1984. Possible explanations of heterozygote deficiency in bivalve molluscs. Malacologia, 25, 583-591. 


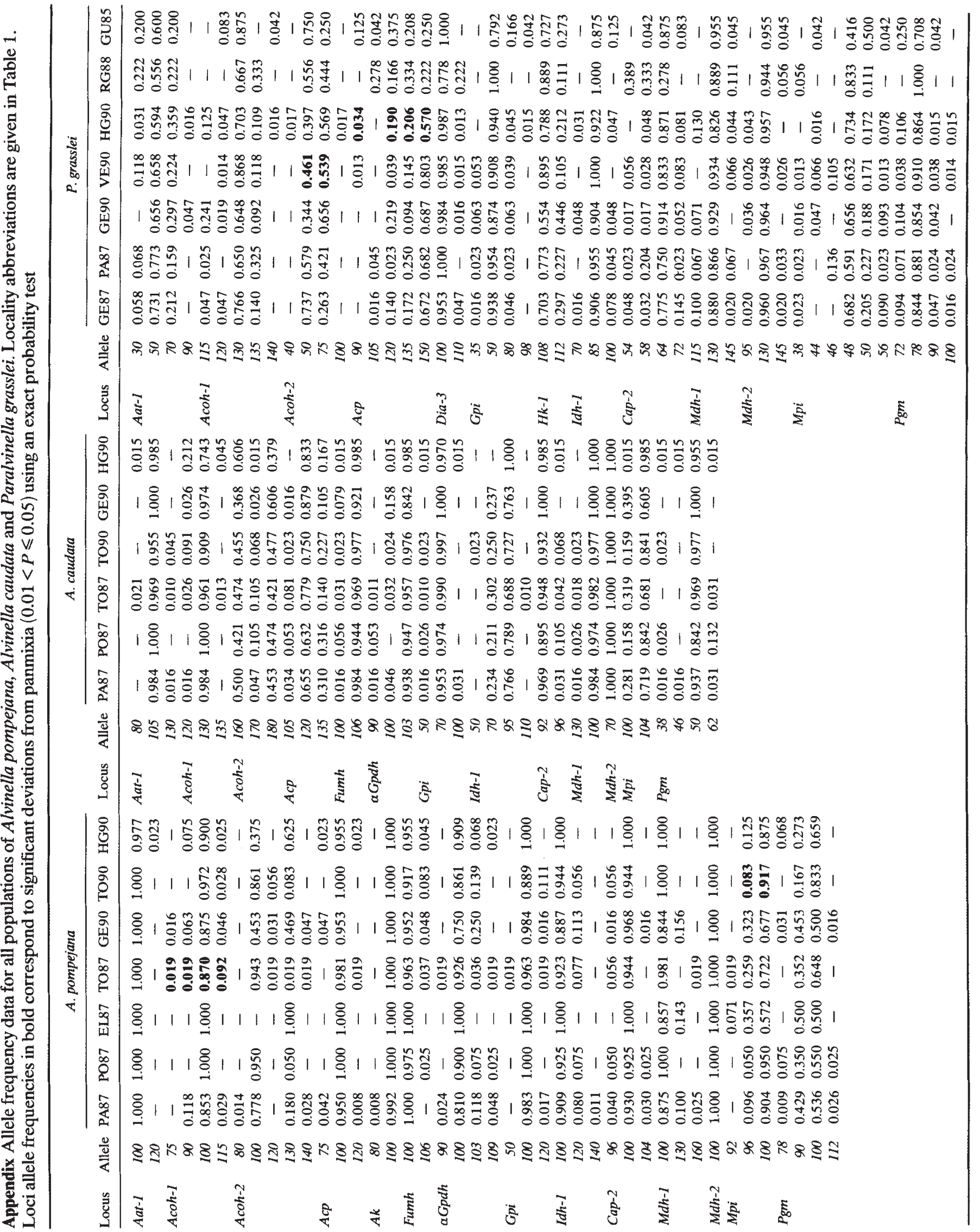

(c) 1995 The Genetical Society of Great Britain, Heredity, 74, 4. 